Review Symposium

\title{
On Brooke Harrington's Capital without Borders: Wealth Managers and the One Percent, Cambridge MA, Harvard University Press, 2016
}

Key words: capitalism, finance, investment banking, inequality, wealth

JEL classification: D31 Personal Income, Wealth, and Their Distributions, F38 International Financial Policy: Financial Transactions Tax; Capital Controls, F39 International Finance: Other, K34 Tax Law

\section{What agency for tax evasion?}

\section{Olivier Godechot*}

Sciences Po Max Planck Sciences Po Center on Coping with Instability in Market Societies (MaxPo), CNRS, Observatoire Sociologique du Changement (OSC, UMR 7049), Paris

*Correspondence: olivier.godechot@sciencespo.fr

Brooke Harrington's Capital without Borders: Wealth Managers and the One Percent is a timely book for many reasons. First, wealth is back (Piketty, 2014)_as a research topic, as a social phenomenon and as a source of public concern. Secondly, a substantial share of world's wealth $(8 \%)$ is hidden in offshore tax havens (Zucman, 2013) and therefore avoids nation-state tax systems. Thirdly, numerous leaks-Luxembourg tax files in 2014, HSBC files in 2015, Panama Papers in 2016, Paradise Papers in 2017-revealed to the world the industrial dimension of tax avoidance. While the extent of this system is now well documented, we do not know how it functions. In a recent interview, Gabriel Zucman urges for more research in this area: 'To fully understand this phenomenon, instead of focusing on fraudsters, we need to study those who help them, this industry of advisors, lawyers, 
bankers who receive high fees. ${ }^{11}$ Harrington provides an important contribution in this direction.

In order to shed light on one of these professions, the wealth managers, Harrington conducted several years of qualitative research: she trained for 2 years as a wealth manager, which led her to acquire both the techniques and the confidence of this profession, and continued with 65 interviews with wealth managers located in 18 countries, ranging from the Cook Islands to San Francisco. She both gave the priority to the world's main tax havens such as Panama (4 interviews), British Virgin Isles (3), Channel Islands (4), but also to larger countries such as the USA (10) and Switzerland (8).

Harrington starts her book with an intriguing history of the medieval origin of wealth managers' activity (Chapter 2). Paradoxically, this profession at the forefront of neoliberalism also relies—like the American pension fund industry (Montagne, 2007)—on a very illiberal form of contract: trust. Hence, this contract dates from the medieval ages where knights heading for a crusade used these managers to protect their wealth during their absence. In order to do so, the settler (the knight) transfers the titles of properties to a benevolent trustee through a trust contract which binds the trustee to manage the property for the benefit of a beneficiary, generally a 'minor' one (the spouse or the children) or the settler himself. Hence, given that one of the parties is seen as a 'minor', those contracts were traditionally subject to equity law (where parties are not viewed as equals) rather than to common law.

Although trusts are not the only contractual device used by wealth managers to protect wealth-they also offer foundations and corporations contracts (cf. the Appendix of Chapter 4 for a detailed comparison)-they encapsulate well the type of service that wealth management provides. Wealth management protects wealth through the transfer of formal property rights from the settler to the trustee. It enables therefore the wealthy to say: 'I'm not the owner', and to avoid all obligations related to wealth. This enables wealth managers to protect wealth not just against taxes, as they are commonly blamed for, but also against many types of stakeholders: the state's changing policies, the business partners or the family incumbents. Beyond tax avoidance, ruling families in unstable states often try to protect themselves against any potential revolution or change in the political regime which would encroach upon their power and question the origin of their wealth. Consequently, recent tax haven leaks showed that, despite insignificant income taxes in their countries, many relatives of authoritarian regime leaders invested heavily in tax havens. Wealth management is also sometimes used to hide wealth from creditors. If the wealthy do not 'own' their wealth, they cannot be forced to repay their debts. Interestingly, this shows that wealth management, often thought as a hyper-capitalist institution, is not just undermining states' power but also capitalism itself by enabling some economic actors to renege on business promises. Finally, wealth managers are also initiated to the deep secrets of the owner's family and can set up devices to protect its wealth against spouses (especially in case of divorce), lovers, official or natural children and help consequently the owner to transmit with great discretion wealth to the favored kin.

Harrington describes in much detail the construction of an intimate long-term relationship between wealth managers and their clients (cf. also Herlin-Giret, 2017). One issue of

1 Gabriel Zucman (2018) 'Comprendre les implications de l'évasion fiscale', Le Monde Economie, 28 May 2018, accessed at https://abonnes.lemonde.fr/idees/article/2018/05/28/gabriel-zucman-compren dre-les-implications-de-I-evasion-fiscale_5305758_3232.html. I translated. 
this intimacy is for wealth managers to build 'trust' and get a deep understanding of the wealth of their customers and how their wealth should be protected against multiple threats. But by doing so, wealth managers also make themselves indispensable and capture the client relationship for their own benefit. As for traders and salespersons in front offices (Godechot, 2017), wealth managers can move from one firm to another with their team and their clients. While these wealth managers serve with great zeal the most intimate wishes of their clients, they also help them to make sense of their fortune (pp. 208-217). Their daily practice insists on the perpetuation and the passing on of the fortune to the next generation rather than its consumption in eccentric projects.

Finally, the book also focuses on the role of wealth managers regarding tax avoidance (pp. 150-154). It describes the great skills these professionals have for exploiting tax loopholes in a given country. They systematically take advantage of differences and even conflicts of jurisdiction. The mobility of the ultra rich and the possibility to 'buy' a passport of many tax havens and pro-wealth countries enable wealth-holders to avoid taxes and if needed to escape prosecutions. Moreover, in tax havens, financial firms not only play with the rule, they also set the rule of offshore financial centers in a sense that is more favorable to their clients (pp. 221-225).

However, the book fails to tackle an important issue in the public debate on wealth managers and tax havens: tax evasion. The book makes a distinction between tax avoidance which is legal and tax evasion which is illegal (p. 150). While it devotes a specific section to the former, it says little about the latter. By focusing more on tax avoidance, the book seems to argue that wealth managers shift the laws rather than break them. Legal tax avoidance is certainly an object of concern. However, governments depended heavily upon recent leaks, especially the HSBC leak, in order to fine fraudsters, thus showing the extension of the illegal use of tax havens. Rich owners from western countries used the tax haven vehicles not only in order to exploit loopholes in the tax systems and to game conflict in jurisdiction. They also omit (probably deliberately) duly declaring interest, dividend or capital gain of their assets stored in tax havens to the tax system of their home country. Hence, Denmark and Norway find that $90-95 \%$ of their citizens owning an account leaked in the HSBC papers did not properly report their income to the tax authority and were thus involved in tax evasion (Alstadsæter et al., 2017).

It would be interesting to understand the origin of this massive fiscal wrongdoing. Does it all come from the clients, who are desperate to cheat on their fiscal declaration, even despite their wealth managers' warnings? Does it all come from the wealth management industry, eager to earn high fees, thereby deliberately minimizing the risks this strategy entails for their clients' wealth and reputation? The book does not offer many answers here. One reason for this may be due to the timing of the research. The author conducted her research in the aftermath of the global financial crisis at a moment where wealth management and tax havens were a source of global outrage. This profession tried to exhibit a sign of good conduct both in reforming its training and in strengthening its compliance code. In this time of uproar, wealth managers are more likely to be very cautious during short interviews of not revealing any of their wrongdoings. Despite claims of moralization of the industry, the most recent leaks still show that tax evasion remains an important motive, if not the main driver, for using these services. Other methods (like participant observation) and other sources (leaks, trials, statistical data, etc.) might therefore help to determine the origins of tax evasion. This question is not just one for social science but also for public policies. Answering it 
would help to set the legal responsibility of wealth managers (both the persons and the employers) in the tax evasion of the clients they advise.

\section{References}

Alstadsæter, A., Johannesen, N. and Zucman, G. (2017) Tax Evasion and Inequality, No. w23772, Cambridge MA, National Bureau of Economic Research.

Godechot, O. (2017) Wages, Bonuses and Appropriation of Profit in the Financial Industry: The Working Rich, London, Routledge.

Herlin-Giret, C. (2017) 'Avoiding and Protesting Taxes: Wealthy People and Tax Consent', Economic Sociology_the European Electronic Newsletter, 19, 29-37.

Montagne, S. (2007) 'In Trusts We Trust: Pension Funds between Social Protection and Financial Speculation', Economic Sociology, 8, 26-32.

Piketty, T. (2014) Capital in the 21st Century, Cambridge, MA, Harvard University Press.

Zucman, G. (2013) 'The Missing Wealth of Nations: Are Europe and the US Net Debtors or Net Creditors?', The Quarterly Journal of Economics, 128, 1321-1364.

\section{Masters of gray zones and elusive champions of the tax 'optimization' industry}

\section{Patrick Emmenegger*}

Department of Political Science, University of St. Gallen, Müller-Friedberg-Strasse 8, 9000 St. Gallen, Switzerland

\section{*Correspondence: patrick.emmenegger@unisg.ch}

There is hardly a more important topic in these times of growing wealth inequalities than the $1 \%$ and their masterful assistants in wealth accumulation and protection. The recent crackdown on offshore finance, most notably by promoting the automatic exchange of information between national tax authorities, has made tax avoidance harder. Yet, it is doubtful that it had much of an effect on the superrich because their tax 'optimization' strategies typically consist of multiple layers and are thus not easily detectable. It is not simply, as The Economist (2013) noted with reference to trusts, that 'only a fool holds dirty money in his own name'. Rather, complex and multi-layered structures are costly and require expertise. They are thus worthwhile for the superrich, but not necessarily for the low-level offenders trying to save some extra money by cheating the taxman.

Little is known about the activities of the superrich. We can sometimes follow their lavish lifestyles on social media (cf. The Rich Kids of Instagram), but we know little about the $1 \%$, which they do not want to share with the larger public. In her magnificent book, Brooke Harrington allows us to catch a glimpse of the superrich. She does so by exploring the activities of the wealth managers that design and maintain complex structures containing their superrich clients' assets. For this purpose, wealth managers variously combine trusts, foundations and shell corporations. The resulting structures often serve multiple ends, including 
laudable ones such as charitable giving and the protection of family businesses. However, such structures can also be used to evade taxation and avoid regulations.

Harrington spared neither trouble nor expense to learn more about the activities of the $1 \%$ wealth managers. In order to gain access to this hidden world, she enrolled in a 2 -year wealth management training program with the London-based Society of Trust and Estate Practitioners (STEP). Having successfully completed the training, she now calls a Trust and Estate Planning (TEP) certificate her own. More importantly, however, the training allowed her to make contacts with practitioners and obtain teaching materials. In many ways, this book forcefully demonstrates what researchers can achieve with dedication and effort.

The book makes several important contributions. In the following, I would like to highlight three in particular. First, in recent years, the debate has mainly focused on the role of banks in tax optimization, while other key actors in offshore finance have managed to avoid the spotlight, among others internationally active law firms, independent wealth managers and tax consulting firms. Banks have drawn a lot of attention not necessarily because they are the worst offenders, but rather because there are clear means states can use to exercise pressure on them. Most notably, banks (even small ones) are dependent on access to the UScontrolled, dollar-based financial system and are thus subject to the power of US law enforcement authorities and regulatory agencies (Emmenegger, 2015; Hakelberg, 2015). However, although important actors in the tax optimization industry (after all, the money has to be stored somewhere), banks rarely have the expertise to design complex structures. Rather, this task is often outsourced to experts such as multinational law and tax consulting firms. ${ }^{2}$ More attention must thus be paid to the role of these tax consultants, lawyers and wealth managers in the tax optimization industry. Harrington provides an excellent start, but others must follow.

Secondly, Harrington makes an important point in demonstrating that while these wealth managers indeed often avoid regulations and thus taxation, they hardly ever break the law. In fact, wealth managers are at great pains to ensure that they are on the right side of the law. However, they are masters at exploring the gray zones of rules and taking advantage of regulatory arbitrage. Consider the tax evasion scandal involving UBS, the world's largest bank in the area of wealth management (cf. Emmenegger and Eggenberger, 2018). The bank seemingly broke US rules because it circumvented the qualified intermediary program (which would have forced it to reveal the identities of its US clients to the US tax authorities) by hiding its clients behind foreign corporations. Yet, using such intermediary structures is perfectly legal, according to US law, as long as their sole purpose is not tax evasion (cf. GAO, 2007, p. 14). ${ }^{3}$ US authorities later ignored this inconvenient fact in the conflict with UBS. For instance, while quoting from the Government Accounting Office (GAO) report to document (legal) means to circumvent the qualified intermediary program, Senators Levin and Coleman (2008, p. 25) simply omitted the word 'legal' in the quote. Yet, as mentioned above, banks are dependent on market access and can thus be more easily forced into punitive agreements. In case of smaller and more elusive actors, there is little law

2 Multinational law firms sometimes even earn additional income because banks purchase legal services from these experts once they have been caught with the very structures these independent experts had designed for them.

3 In fact, tax optimization by means of such shell corporations whose owners do not have to be disclosed is an excellent example of how the USA facilitates tax optimization (Findley et al., 2014). 
enforcement authorities can do. Hence, attempts to change the tax optimization industry must involve the wealth managers themselves (Hofri-Winogradow, 2014).

Finally, Harrington shows how (some) states protect the tax optimization industry, even if their business is illicit. Her main focus lies on how the tax optimization industry captures weak states. However, the problem goes beyond such cases. As Rixen (2008) shows, multilateral tax cooperation is best understood as an asymmetrical prisoners' dilemma, in which cooperative solutions are difficult to achieve as long as states can hope to benefit from tax optimization. In fact, some countries have even benefitted from the recent crackdown on some offshore financial centers by diverting illicit funds to their 'tax havens' (Johannesen and Zucman, 2014). Sadly, USA is among the main beneficiaries of these flows (Hakelberg and Schaub, 2018), which goes a long way in explaining why USA still refuses to fully participate in the new regime of automatic exchange of information in tax matters. Progress can only be expected when states are inadvertently caught in the act of facilitating tax evasion (Emmenegger, 2017). In contrast, multilateral initiatives are unlikely to succeed. As Strange (1998, p. 132) has already noted 20 years ago:

If the Group of Seven were to announce that they would be publishing a blacklist of the known tax havens and another blacklist of the firms and individuals actively making use of tax havens, and would impose fines or other sanctions on them unless the accounts were closed within a specified time, there can be little doubt that most could not survive for very long. The reasons why this does not happen are, once again, political rather than technical.

Powerful states like USA, Russia, Great Britain or China have little interest in putting an end to the tax optimization industry because they are too involved themselves. As Stone (2011) observes, powerful states only join international organizations when they know that the organizations' rules do not apply to them. Why would USA stop the tax optimization industry if they are a key part of it?

What can be done about the tax optimization industry and, in the context of this book symposium, its elusive champions, that is, the wealth management experts? One way could be to give law enforcement authorities more resources, but as long as more money can be made by working for the tax optimization industry, this arms race cannot be won. Deterrence by means of larger fines could be an alternative, but for this to work, perpetrators have to be first caught. And as mentioned above, wealth managers hardly ever break the law. For the same reasons, senior-level managers have been able to avoid jail although their banks were forced to agree to punitive settlements. Encouraging whistleblowers to come forward is another answer, but these persons must be protected-even when they are of questionable character themselves. Yet, whistleblowers are most effective in case of large corporations. In contrast, in case of smaller and more elusive actors such as wealth management professionals, whistleblowers are unlikely to be the solution.

Harrington suggests another alternative, although she does not discuss it very explicitly. Towards the end of the book, she argues that 'political leaders interested in seeing elites pay their fair share of tax and otherwise submit to the rule of law should shift their attention away from the wealthy individuals and onto the professionals who serve them' (p. 303). The reason is that because wealth management professionals are simply too good at what they do, states must change their incentive structure, thereby turning wealth management specialists from allies of the superrich into international compliance experts. Put differently, wealth managers should be turned from part of the problem to part of the solution. 
The key to this change might be found in the professional standards. For instance, Harrington notes that in the introductory course for the TEP diploma, the first 28 pages $(11 \%)$ of the textbook were devoted to a discussion of how offshore financial centers can be used to defend private fortunes. According to Harrington (p. 150), STEP 'frames tax avoidance as a form of self-defense against illegitimate exercise of government authority'. Yet wealth management practitioners need not be socialized like this into their profession. ${ }^{4}$ In her discussion of the origins of wealth management in the medieval practice of trusteeship, Harrington (pp. 36-46) notes how there were very few legal means to stop wealth managers from abusing their powerful position. Therefore, the wealth managers' unique cultural and social position was intimately tied to feudal customs and strong norms of honor, which also explains why they were initially not remunerated for their services. Rather, to be chosen as wealth manager affirmed one's high social status as a person of trust. In some way, Harrington's description of the origins of the profession could also be read as a plea to change it back to its origins.

\section{References}

Emmenegger, P. (2015) 'The Long Arm of Justice: US Structural Power and International Banking', Business and Politics, 17, 473-493.

Emmenegger, P. (2017) 'Swiss Banking Secrecy and the Problem of International Tax Cooperation: A Nut Too Hard to Crack?', Regulation \& Governance, 11, 24-40.

Emmenegger, P. and Eggenberger, K. (2018) 'State Sovereignty, Economic Interdependence and US Extraterritoriality: The Demise of Swiss Banking Secrecy and the Re-Embedding of International Finance', Journal of International Relations and Development, 21, 798-823.

Findley, M. G., Nielson, D. L. and Sharman, J. C. (2014) Global Shell Games: Experiments in Transnational Relations, Crime, and Terrorism, Cambridge, MA, Cambridge University Press.

GAO (2007) Tax Compliance: Qualified Intermediary Program Provides Some Assurance That Taxes on Foreign Investors Are Withheld and Reported, but Can Be Improved, Washington, WA, United States Government Accountability Office.

Hakelberg, L. (2015) 'The Power Politics of International Tax Co-operation: Luxembourg, Austria and the Automatic Exchange of Information', Journal of European Public Policy, 15, 409-428.

Hakelberg, L. and Schaub, M. (2018) 'The Redistributive Impact of Hypocrisy in International Taxation', Regulation \& Governance, 12, 353-370.

Hofri-Winogradow, A. S. (2014) 'Professionals' Contribution to the Legislative Process: Between Self, Client, and the Public', Law \& Social Inquiry, 39, 96-126.

Johannesen, N. and Zucman, G. (2014) 'The End of Bank Secrecy? An Evaluation of the G20 Tax Haven Crackdown', American Economic Journal: Economic Policy, 6, 65-91.

Levin, C. and Coleman, N. (2008) Tax Haven Banks and US Tax Compliance. Staff Report of Permanent Subcommittee on Investigations, Washington, WA, United States Senate.

Rixen, T. (2008) The Political Economy of International Tax Governance, Houndmills, Palgrave Macmillan.

Stone, R. W. (2011) Controlling Institutions: International Organizations and the Global Economy, Cambridge, MA, Cambridge University Press.

Strange, S. (1998) Mad Money: When Markets Outgrow Governments, Ann Arbor, MI, University of Michigan Press.

The Economist (2013, November 9) 'Dirty Money: Mistrust the Trusts'. London, The Economist.

4 And certainly not all of them are, but already a minority may cause great societal damage. 


\section{A look at wealth managers: some methodological and rhetorical considerations}

\section{Patrick Inglis*}

Department of Sociology, Grinnell College, Grinnell, IA, USA

\section{*Correspondence: inglispa@grinnell.edu}

In a new book, Brooke Harrington helps to improve our understanding of global inequality with a look at the cadre of accountants, lawyers and other highly educated white-collar professionals who serve the rich in a variety of capacities, but always with one aim-to keep their money safe and hidden, no matter the consequences to the rest of us. Deploying measures both legal and quasi-legal, these wealth managers, as they are called, help the rich stash money away in offshare tax havens and domestic and international shell companies. They also lay the groundwork for foundations and trusts, some legitimate, but many not, propped up on the fantasy that they support the public good, when too often they do no such thing. Out of sight, and out of our collective minds, the money grows, not so much because of any special ingenuity on the part of the rich, or the people they employ in this capacity, but because they have money in the first place, and the good sense to know where to put it. The book is excellent, as fellow critics in this symposium will attest, and as I have suggested elsewhere in a longer review that addresses key themes and arguments (Inglis, 2018). Here, I want to use the occasion to consider Harrington's methods of inquiry. With that in mind, I focus less on what Harrington discovered than the decisions that she made in reporting these findings.

To begin, let me say that the mixed-methods approach Harrington describes, combining mainly ethnography paired with lengthy sit-down interviews with wealth managers, is impressive. The history of wealth management she provides, going all the way back to the Middle Ages, is also a welcome complement, and a real strength of the book. As part of this history, Harrington tracks the professionalization of wealth management to innovations of modern capitalism in the twentieth century, culminating in the first professional association, the London-based Society of Trust and Estate Practitioners (STEP), founded in 1991. As a researcher, she effectively uses her self-declared status as a white native English speaker 'possessed of an upper-middle class habitus' (p. 27) to navigate access to these individuals and the exclusive social spaces within which they circulate. Most impressive of all, she signs up for a 2-year course in wealth management, offered by STEP, which nets her a Trust and Estate Planner certificate, and with it the necessary connections for carrying out the interviews that make up the bulk of this book.

Harrington is a participant-observer in this world, she announces, billing the study as an 'immersion ethnography' (p. 274). If I have one complaint, though, it is that Harrington too 
often privileges the observer over the participant in the telling. At a rhetorical level, Harrington's strategy seems to be to let wealth managers speak without interruption, while removing herself completely from the scene. It is an odd decision, not only because Harrington is, presumably, right there, but also because she did the work to earn the title of wealth manager, even if she never practices professionally. She takes the classes, as mentioned, attends the professional meetings and then proceeds to travel the world to meet these wealth managers in secluded hotels, bars and country clubs-all told, between 2008 and 2015 Harrington interviewed 65 wealth managers, a majority of them men, working in as many as 18 countries. She knows these people extremely well. She is one of them, even though she is not, and yet the reader does not always reap the benefit of this insider status.

It is not like Harrington is some neutral observer, either. Her outrage at the state of inequality in the world and the role of wealth management in producing it is never in question, and rightfully so. In the last two chapters of the book, Harrington is especially frank about the consequences wealth management brings to bear on revenue-starved nation-states and overburdened citizens who lack the requisite money and know-how to skip out on their taxes. Yet this, too, left me wanting more in the way of some deeper insights into the personal motivation and psyche of the wealth manages she meets. As she writes, 'Inequality is problematic when it creates multigenerational barriers to the availability of capital, education, employment, and political representation' (p. 198). Harrington also shows deep concern about the 'dynastic wealth' (p. 208) wealth managers facilitate that commits a majority of the world's population to toil and misery-their ability to achieve this very thing, of course, accounts for success or failure in this line of work. What of her informants, though? But for one or two informants who relate some self-doubt or moral conscience about these activities, most refuse to say. Nor is it clear if Harrington did, in fact, challenge informants' base assumptions at all.

Indeed, while there are plenty of quotes throughout the text, there is no dialog, no back and forth on any of the many overarching controversial themes that Harrington otherwise does so well to highlight. This is a missed opportunity, in my view, given how rare it is to win an audience with these kinds of individuals, and rarer still to be trained alongside them learning the tricks of this particular trade. I am not entirely surprised by this, mind you. Undoubtedly, Harrington was required to sign strict confidentiality agreements with all informants, barring her from reporting on any specifics about them or their clients. All the same, it seems to me that the boundaries of ethnographic license might have been pushed further. What kinds of moral dilemmas do wealth mangers face, if any? How far are they willing to go for their clients? How do they justify this activity, in the face of so much inequality? Harrington broaches some, though by no means all, of these questions, and often in the abstract, without reference to any specific informant, despite the fact that their identities could easily be hidden. Thus, by the end of the book, we have a good sense of what these wealth managers do, the strings they pull and the kinds of people they work for. We have less of a sense of who they are as people, even as Harrington brings us so tantalizingly close to them.

Again, I wonder what more might have been revealed about this group and the wealth management industry as a whole if Harrington had emphasized the participant in her fieldwork as much as she does the observer. This likely would have required centering the narrative on a handful of wealth managers, say, eight to ten, for example, and detailing their everyday lives, who they meet, when, where, and why, as opposed to splitting time, and 
words, with the dozens who appear in these pages, and often, if inevitably, in twodimensional form. This would have also likely resulted in a different kind of book, I realize. That is no mark on this one, to be sure. For now, let us celebrate it, and register a note of thanks, and not a little bit of awe, at what Harrington has accomplished with this study.

\section{Reference}

Inglis, P. (2018) 'Review of Capital without Borders: Wealth Managers and the One Percent by Brooke Harrington', Industrial and Labor Relations Review, 71, 559-561. 